\title{
IDENTIFYING INITIAL DAMAGE OF PALM OIL SCREW PRESS OF DRIVE SHAFT
}

\author{
Purwo Subekti ${ }^{1}$, Eddy Elfiano ${ }^{2}$, Legisnal Hakim ${ }^{3}$, Andi Rizki $^{4 \&}$ Saiful Anwar $^{5}$ \\ ${ }^{1}$ Mechanical Engineering University of Pasir Pengaraian, Indonesia \\ ${ }^{2}$ Mechanical Engineering Islamic University of Riau, Indonesia \\ ${ }^{3}$ Mechanical Engineering Muhammadiah University of Riau, Indonesia \\ ${ }^{4}$ Teacher Training and Education University of Pasir Pengaraian, Indonesia \\ ${ }^{5}$ Mechanical Engineering University of Pasir Pengaraian, Indonesia \\ e-mail :saifula160@gmail.com
}

\begin{abstract}
ABSTRACT: Investigation was carried out because of the common failure at the screw press of drive shaft which made disruption on production activity of palm oil. Visual observation, interview and simulation were conducted. The finding supported by simulation using Nastran statistical software showed that the fracture occurred due to the fatigue. Based on simulation, it was known that the stress concentration occured on the keyway of the tooth wheel holder. It was proved by visual observation which showed the attrition of keyway due to the friction between post and keyway continuously occured in the drive shaft rotation. The continuously friction leaded to the loosening of the keyway. Futhermore,it made the strong impulse to the post keyway which finally caused the fracture at the keyway area. The continuously operating drive shaft caused the final fracture. The several characteristic of fatigue fracture could be seen from the fracture surface, such as the presence of residual fracture area, smooth surface and the presence of beach marks.
\end{abstract}

Keywords: Screw Press, Drive Shaft, Stress Concentration, Beach Mark

\section{INTRODUCTION}

One of the important factors determining the success of palm oil plantation is the processing step. The existence of equipment processing fresh fruit bunches ( FFB ) is very necessary to produce crude palm oil ( CPO ) as the primary outcome and palm kernel, shell , empty fruit bunches, fibers and liquid waste. That is why it should be maintained properly to prevent a disruption in the process of production.

If a disruption occurs in the components of the equipment, the processing of palm fruit into crude palm oil engenders some negative effects such as the demage of raw material (fresh fruit bunches), the missing of target production, the increase of production cost and the discontinuity supply of products. In addition, it will reduce the number productivity index of factory, so the factory will suffer a loss from operation.

Based on the study, during 2003-2005, the amount of stagnation of CPO was 2749.33 tons and PK ( Palm Kernel ) was 555.70 tonnes as the result of the failure of machine. It also found that the Screw Press was the machinery / equipment 
which had $34.24 \%$ contribution rate of failure and decline in production [1]. .

According Barabady (2005), the performance of machinery / equipment depends on ; reliability and availability of the equipment used, the operating environment, the efficiency of maintenance, the operating process and the expertise of operators. If the reliability and availability of a system is low, the effort to increase it is reducing the rate of failure or making efficient improvements to each component or system. To optimize the reliability and the availability, the maintenance strategies consisting of Design-out Maintenance, Preventive Maintenance and Corrective Maintenance are needed [2].
The draft maintenance strategy of machine should be developed based on analysis of characteristics / performance of the machines used. By analyzing the characteristics of the engine and critical components, the draft maintenance strategy will be able to reduce the level of damage system and make the lower operating costs. Machinery and critical components which are damaged may result cessation of production (downtime). The engine damage of PPKS data in one of the Palm Oil Processing factory in North Sumatra from January 2007 to August 2009 was taken. The maintenance record showed the frequency of engine failure in PPKS. To determine the largest frequency of failure machines sequence, a Pareto diagram was used as in the Figure [3] :

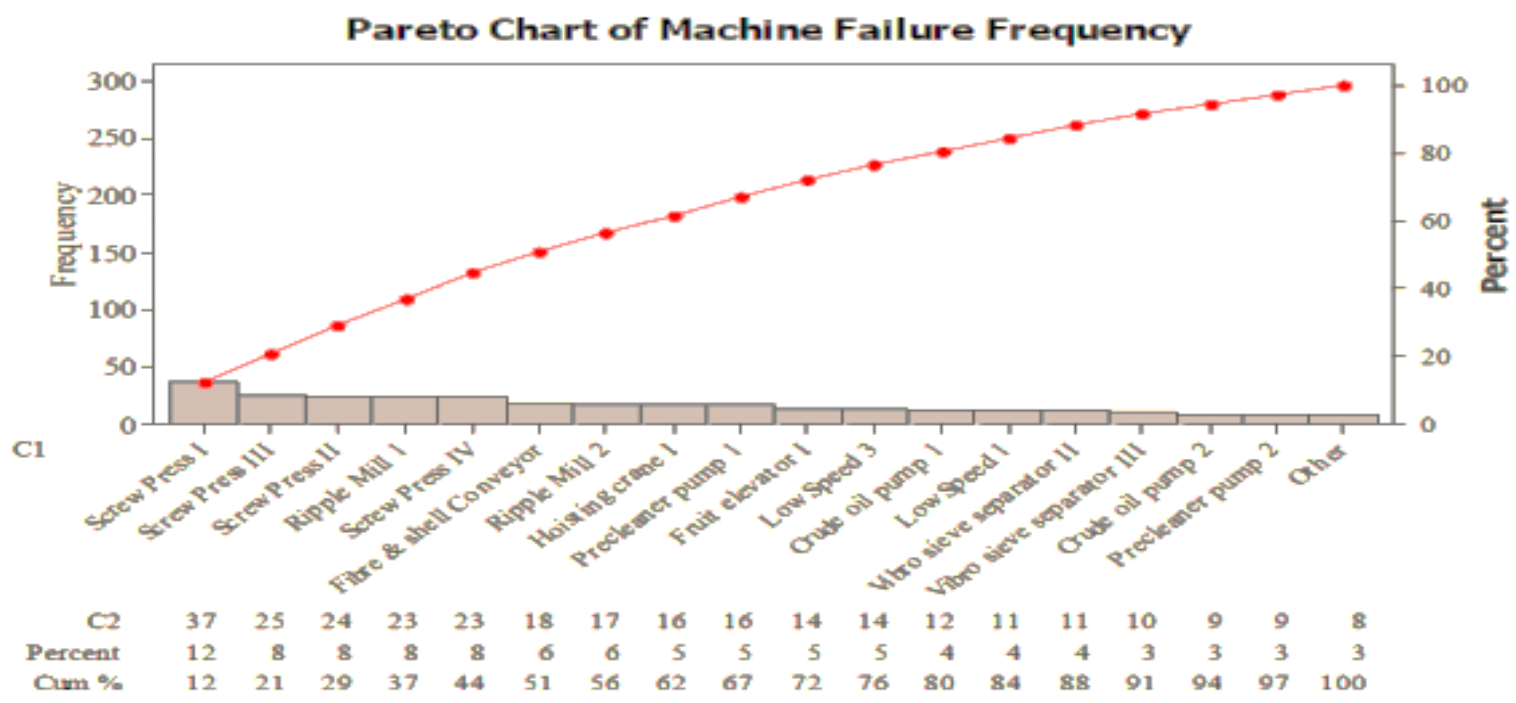

Figure 1. Frequency of failure process engineering at the MCC [ 3 ]

Figure 1 showed that the greatest frequency of failure happened at Screw Press. The frequent failure of the drive shaft on the Screw Press would reduce the productivity of the company . It automatically leaded to the increase of the company's operating costs as a result of the cessation of the Screw Press unit. 


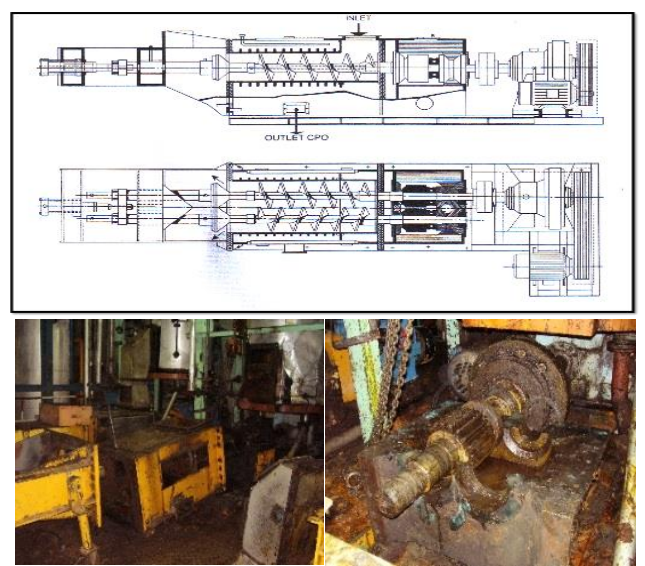

Figure 2. Screw Press

Source : Universal Steel and PT . Minamas

In component, if screw press was damaged, the process of mounting the drive shaft is the most complicated and it needs a lot of time. The high levels damage of screw press within a year will increase the downtime that would burden the cost of spare parts and the operations of the company.

\section{RESEARCH METHODS}

This research procedures focused on identifying the damage of screw press of the drive shaft including :

\section{a. Visualization of field}

Inspection of the damage in screw press units, interview with operators and knowing the track record of operational components of the drive shaft were done .

\section{b . Simulation analysis of stress}

To analyze the power of screw press of the drive shaft in receiveing the twisting force, tap and drag, the several standard procedures of data processing were done. They are pre - processing , processing and post-processing .

\section{c. Conclusions and Recommendations}

The results analysis of the steps above was done to find out the cause and prevention of the damage of the drive shaft components.

\section{RESULTS AND DISCUSSION}

\subsection{Visualization of Field}

Material of screw press of the drive shaft that often fracture, namely 709 ASSAB steel ( AISI / SAE 4140

) with chemical compositions as follows :

Table 1 Chemical composition of standard steel ASSAB 709

\begin{tabular}{|c|c|c|c|c|c|}
\hline Material & $\mathrm{C} \%$ & $\mathrm{Si} \%$ & Mn\% & $\begin{array}{l}\mathrm{Cr} \\
\%\end{array}$ & Мo\% \\
\hline ASSAB 709 & 0.42 & 0.25 & 0.75 & 1.05 & 0.20 \\
\hline \multicolumn{6}{|c|}{ Mechanical Properties } \\
\hline \multicolumn{3}{|l|}{ Yield Strength } & \multicolumn{3}{|c|}{$600 \mathrm{~N} / \mathrm{mm}^{2}$} \\
\hline \multicolumn{3}{|c|}{ Tensile Strength } & \multicolumn{3}{|c|}{$800-950 \mathrm{~N} / \mathrm{mm}^{2}$} \\
\hline \multicolumn{3}{|l|}{ Elongation } & \multicolumn{3}{|c|}{$14 \%$} \\
\hline \multicolumn{3}{|c|}{ Reduction of Area } & \multicolumn{3}{|c|}{$\min .55 \%$} \\
\hline \multicolumn{3}{|c|}{ Impact Strength } & \multicolumn{3}{|c|}{25 Joule } \\
\hline \multicolumn{3}{|l|}{ Hardness } & \multicolumn{3}{|c|}{ 245-290 HB } \\
\hline
\end{tabular}

Source : ( ASSAB Steel of Indonesia )
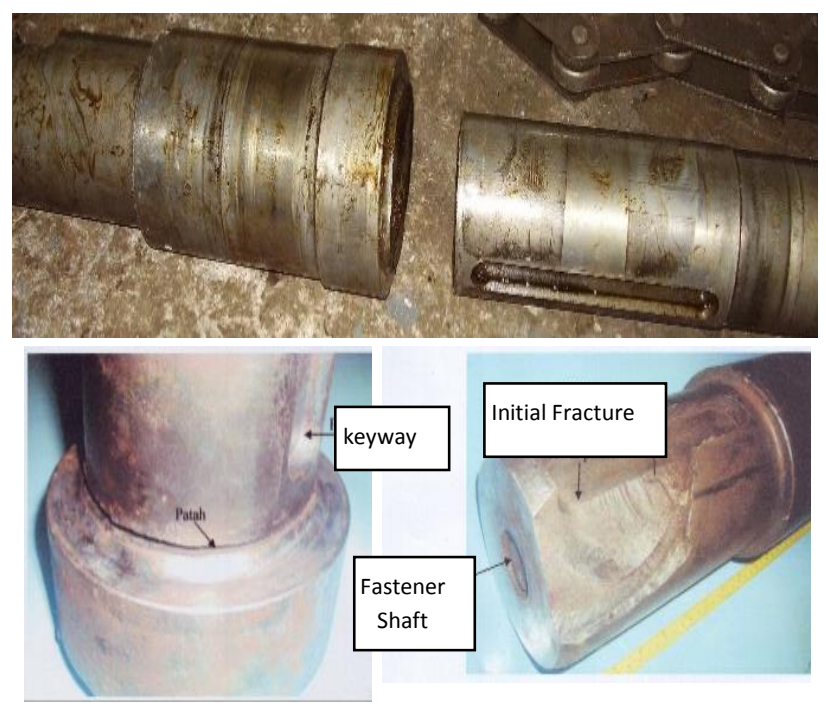

Figure 3. The fracture of screw press of the drive shaft 


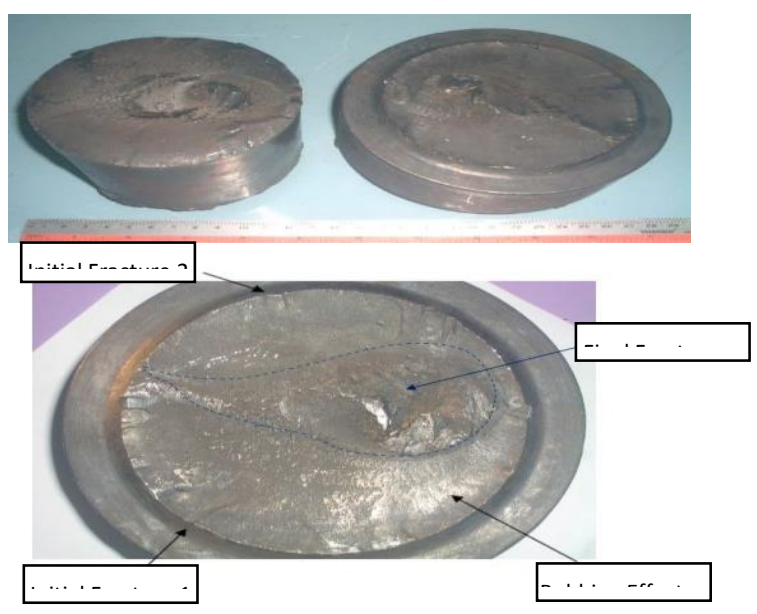

Figure 4. The fracture surface because of rotating bending

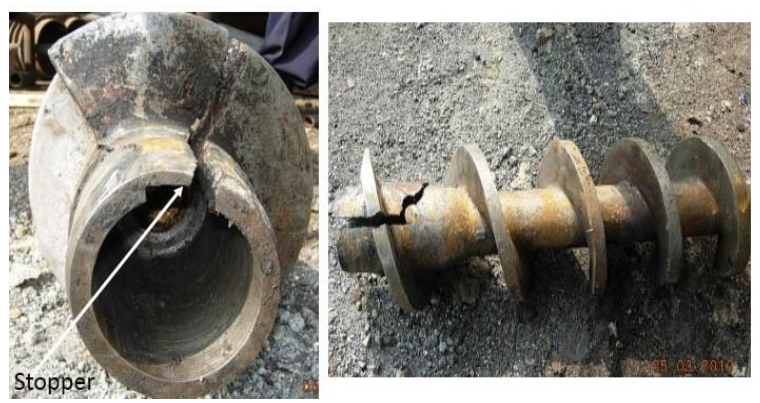

Figure 5. Worm screw damaged

Based on the observations on the photographs of the fracture surface in the shaft, the expected area as crack initiation, and the crack propagation spreading into the shaping beach mark shown in Figure 4 were done. The final fracture occured in end of the cycle stress when the rest of the shaft cross-section no longer able to withstand the load of shaft . Fatigue fracture could be recognized from the fracture surface. It was smooth due to the rubbing effect when the crack spread as a result of loading cycles, while the final fracture surface looks rough (Figure 4)

\subsection{Simulation Analysis of Stress}

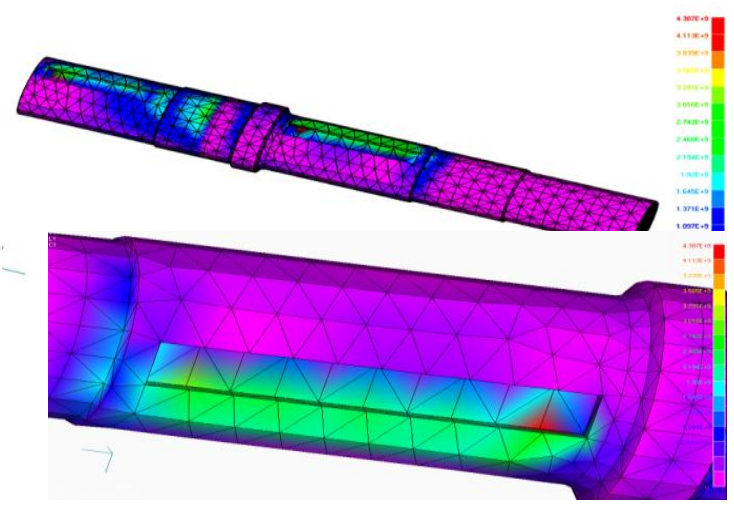

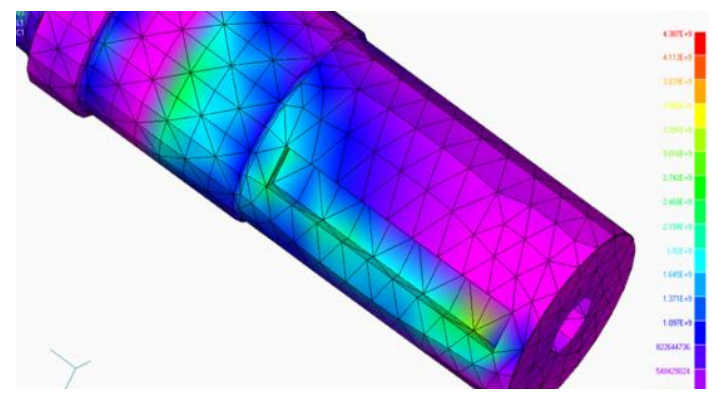

Figure 6. Contour concentration stress in dive shaft [4]

Based on the stress simulation results using MSC Nastran software as shown in the Figure 6 shows that the maximum stress (to the power of shaft) that occurs in the shaft was $4.387 \mathrm{E}+9=4387000000 \mathrm{kpsi} / 6,895 \mathrm{x}$ $10^{6}=636,26 \mathrm{~N} / \mathrm{mm}^{2}$. It explained that the stress that occured was still in the safe limits of tensile strength which is $800-950 \mathrm{~N} / \mathrm{mm} 2$ (Table 1). However, the concentration of stress occured on the keyway area and it made uneven distribution of stress on the shaft so that the fatigue happened in that area. If the allowable shear stress corrected is greater than the shear stress that occurs on the basis of the shaft without a keyway, the dimension of the shaft is safe / good. But if the result is less, redesign must be done to make the greater results [5].

\section{CONCLUSIONS AND RECOMMENDATIONS}

\subsection{Conclusions}

From the results of visual inspection and stress simulation, it can be concluded that indication of the Drive Shaft fractures is caused by several factors:

1. The effect of loose-fitting post on the worm screw of the drive shaft. In addition, the concentration of stress on the keyway area (figure 6) makes rotating bending at the worm screw. It can be recognized by the presence of cracks / damage in the worm screw stopper area (Figure 5). Finally, it lead to the 
beat on the bearing continuously, so that the pads wear out and rotating bending happens in the shaft.

2. The rotating bending causes the loose-fitting of pegs in tooth whell which leads to the beat / clash between two tooth whells, so that the reverse impetus occurs from driving gears in the fillet. Those indications are strengthened by figure 4 and 6. These phenomena continously happens during the operation of drive shaft, until the loose-fitting and the scrape continously happens in keyway area (figure 3). The friction between the peg and keyway cause continuous collisions which makes cracks and spread into the final fracture (Figure 4).

\subsection{Recommendations}

To ensure the damage, laboratory tests that can support the cause and prevention of damage to the drive shaft are needed. They are as follows:

1. A test of material hardness, clams composition , tensile, metallographic and SEM.

2. A heat treatment process on the drive shaft so that the material yield strength increases.

3. An analysis of friction in the keyway of the drive shaft and the worm screw stopper.

4. An analysis of friction in the keyway of the drive shaft and the keyway of the tooth wheel 5. An analysis of vibration in the worm screw.

5. A penetrant test to hub screw worm before the operation and during maintenance.

6. A control to make sure the dough in degester that goes to screw press does not lack of water because it can reduce the burden of pressure.

\section{REFERENCES}

Sitorus, Holden. "Pengebangan Sistem Pemeliharaan Peralatan Industri (Studi Kasus Pemeliharaan Peralatan Mesin Pabrik Kelapa Sawit PT.Tor Ganda)", Tesis: Universitas Sumatera Utara, 2006.
Barabady. J, "Improvement of System Availability Using Reliability and Maintainability Analysis", Thesis: Division of Operation and Maintenance Engineering, Lulea University of Technology, Sweden 2005

Yuhelson, Bustami.S, Sinullingga. S, Isranuri. I, "Analisis Reliability Dan Availability Mesin Pabrik Kelapa Sawit PT. Perkebunan Nusantara" 3, Jurnal Dinamis, Vol. II, No. 6, Januari, 2010, pp. 6-22.

Analysis Guide, MSC.Nastran for Windows v4.5, Msc.Software Corp, 1999.

W.O. Alexander, "Dasar Metalurgi Untuk Rekayasawan", PT. Gramedia Pusaka Utama, Jakarta, 1995.

Alfian. H, "Manajemen Pemeliharaan Pabrik", eUSU Repository, Universitas Sumatera Utara, 2004.

Bruzek B., Leidich E, Numerical Simulation Of Stresses In Thin-Rimmed Spur Gears With Keyway, Acta Polytechnica Journal of Advanced Engineering, Vol. 43, No. 5, Scientific Journal of the Czech Technical University in Prague (CTU), 2003, pp. 47-53.

Budiwantoro. B., Hermawan. A.T, Desain Geometri Screw Press Dengan Metode Numerik Elmen Hingga, Jurnal Teknik Mesin, Vol. 17, No. 1, ITB, Bandung, 2002

Devi. C, Kaji Eksperimen Peningkatan Umur Lelah Poros Beralur Dengan Penambahan Alur Bantu, Jurnal Teknika, No.3,2 Vol.1, Thn. XVI, Jurusan Teknik Mesin Fakultas Teknik Universitas Andalas, Padang, 2009, pp.

Gujar. A , Bhaskar. SV, Shaft Design under Fatigue Loading By Using Modified Goodman Method, International Journal of Engineering Research and Applications (IJERA) Vol . 3 , Issue 4, 2013, pp.1061 -1066.

Kuncoro. D. Jamasri, Karakteristik Lelah Poros Baja S45c Bertakik V Akibat Beban Amplitude Konstan Dan Beban Tiba-Tiba, Media Teknik, No.1 tahun XXIII, Fakultas teknik Universitas Gadjah Mada, 2001.

Pedersen. N.L, Optimization of Keyway Design, 2nd International Conference on Engineering Optimization, Lisbon, Portugal , 2010. 